\title{
Lactobacillus delbrueckii subsp. indicus subsp. nov., isolated from Indian dairy products
}

Correspondence

Franco Dellaglio

franco.dellaglio@univr.it

\author{
Franco Dellaglio, ${ }^{1}$ Giovanna E. Felis, ${ }^{1}$ Anna Castioni, ${ }^{1}$ Sandra Torriani ${ }^{1}$ \\ and Jacques-Edouard Germond ${ }^{2}$
}

${ }^{1}$ Dipartimento Scientifico e Tecnologico, Facoltà di Scienze MM. FF. NN., Università degli Studi di Verona, Italy

${ }^{2}$ Nestlé Research Centre, Nestec Ltd, Lausanne, Switzerland

\begin{abstract}
Four strains isolated from Indian dairy products and initially identified as Lactobacillus delbrueckii could not be assigned to a definite subspecies because molecular identification and phenotypic traits did not agree with those of recognized subspecies of $L$. delbrueckii. Hybridization of total DNA (78-86\% against type strains of the other three subspecies), AFLP and RAPD-PCR fingerprints, phylogenetic analysis based on 16S rRNA gene sequences and sequence analysis of two coding genes ( $r e c A$ and $h s p 60$ ), together with phenotypic profiles, indicated that the four strains form a coherent cluster and represent a novel subspecies, for which the name Lactobacillus delbrueckii subsp. indicus subsp. nov. is proposed. The type strain is $\mathrm{NCC} 725^{\top}\left(=\right.$ LMG $22083^{\top}=$ DSM $\left.15996^{\top}\right)$.
\end{abstract}

Lactobacillus delbrueckii is the type species of the genus Lactobacillus and comprises three subspecies, Lactobacillus delbrueckii subsp. delbrueckii, Lactobacillus delbrueckii subsp. lactis and Lactobacillus delbrueckii subsp. bulgaricus (Weiss et al., 1983). Strains belonging to the three subspecies show a high degree of DNA-DNA relatedness but can be differentiated on the basis of different phenotypic traits (Weiss et al., 1983; Kandler \& Weiss, 1989).

In a previous study regarding the evolutionary structure of the species L. delbrueckii (Germond et al., 2003), a number of lactobacilli originating from five dairy fermented products from India were analysed. Among those lactobacilli, four strains isolated from traditional Indian dairy fermented (type Dahi) products were identified as L. delbrueckii on the basis of molecular and phenotypic evidence, i.e. hybridization with a probe specific for L. delbrueckii, pY85 (Delley et al., 1990), typing based on digested genomic DNA probed

The GenBank/EMBL/DDBJ accession number for the 16S rRNA gene sequence of Lactobacillus delbrueckii subsp. indicus $\mathrm{NCC}^{2} \mathrm{~S}^{\top}$ is AY421720; partial recA gene sequences of $L$. delbrueckii subsp. delbrueckii NCC621 ${ }^{\top}$, AJ586863; L. delbrueckii subsp. bulgaricus NCC641 ${ }^{\top}$, AJ586864; L. delbrueckii subsp. lactis NCC946 ${ }^{\top}$, AJ586865; L. delbrueckii subsp. indicus NCC665, AJ586866; L. delbrueckii subsp. indicus NCC780, AJ586867; and partial hsp60 gene sequences of $L$. delbrueckii subsp. delbrueckii NCC621 $1^{\top}$, AJ586868; L. delbrueckii subsp. bulgaricus NCC641 ${ }^{\top}$, AJ586869; L. delbrueckii subsp. lactis NCC946', AJ586870; L. delbrueckii subsp. indicus NCC725 ${ }^{\top}$, AJ586872; L. delbrueckii subsp. indicus NCC665, AJ586871.

A partial phylogenetic tree, AFLP ${ }^{(i x}$ and RAPD profiles, and distinguishing characteristics of the subspecies of Lactobacillus delbrueckii are available as supplementary material in IJSEM Online. with ribosomal or ISL7 sequences, specific PCR amplification and the exclusive production of D-lactate from lactose. However, they could not be assigned to one of the known subspecies of $L$. delbrueckii because they presented atypical characteristics such as the ability of $L$. delbrueckii subsp. bulgaricus to degrade lactose constitutively, but no amplification of the gene encoding $\beta$-galactosidase using specific primers for L. delbrueckii subsp. bulgaricus and L. delbrueckii subsp. lactis.

We report here the polyphasic analysis performed to define the taxonomic position of the four strains and describe a novel subspecies for $L$. delbrueckii.

The bacterial strains $\mathrm{NCC}^{2} 5^{\mathrm{T}}$, NCC665, NCC757 and NCC780 and the type strains of $L$. delbrueckii subsp. delbrueckii NCC621 ${ }^{\mathrm{T}}\left(=\right.$ ATCC $\left.9649^{\mathrm{T}}=\mathrm{LMG} 6412^{\mathrm{T}}\right), L$. delbrueckii subsp. lactis NCC946 ${ }^{\mathrm{T}}\left(=\right.$ ATCC $12315^{\mathrm{T}}=\mathrm{LMG}$ $7942^{\mathrm{T}}$ ) and L. delbrueckii subsp. bulgaricus $\mathrm{NCC}^{\mathrm{T}} \mathrm{T}^{\mathrm{T}}$ $\left(=\right.$ ATCC $11842^{\mathrm{T}}=$ LMG $\left.6901^{\mathrm{T}}\right)$ were grown in de ManRogosa-Sharpe (MRS) or acidified MRS (pH 5.4) medium at $37^{\circ} \mathrm{C}$.

Sugar metabolism was evaluated using the API-50CH detection kit. All strains tested fermented glucose, fructose and mannose. The ability to metabolize lactose distinguished the four strains from L. delbrueckii subsp. delbrueckii. These four strains can also be differentiated from $L$. delbrueckii subsp. lactis because they did not ferment both maltose and trehalose. Three of the four strains (except NCC757) fermented sucrose and not $\mathrm{N}$-acetylglucosamine in contrast to type strains of $L$. delbrueckii subsp. bulgaricus and $L$. delbrueckii subsp. lactis, respectively. 
DNA for specific amplification and Southern blot analysis was extracted according to the methods of Marmur (1961) and Germond et al. (2003), respectively. Ribotyping and insertion sequence (IS) typing identification results showed a closer relationship of the four Indian strains to L. delbrueckii subsp. lactis than to the other two recognized subspecies (Germond et al., 2003).

Subspecies-specific identification was performed by DNA amplification using a combination of primers designed on the proline iminopeptidase (pepIP) gene of $L$. delbrueckii subsp. bulgaricus (Torriani et al., 1999): this test allows us to differentiate between $L$. delbrueckii subsp. lactis and L. delbrueckii subsp. bulgaricus on the basis of the length of the amplification product, while L. delbrueckii subsp. delbrueckii should show no amplification. The four Indian strains were all negative for the assay (data not shown), even if DNA was present at the appropriate concentration and was able to be amplified, as verified by RAPD-PCR analyses.

16S rRNA gene amplifications and sequences were obtained as reported by Germond et al. (2003). Sequence alignments were obtained using the CLUSTAL_X program (Thompson et al., 1997). Phylogenetic analysis was conducted using MEGA version 2.1 (Kumar et al., 2001): distance analysis (Tamura's three-parameter distance) and neighbourjoining clustering were applied, as well as the maximumparsimony method using default options. An analysis of the robustness of the trees was obtained by a bootstrap approach with 1000 replicates. A maximum-likelihood analysis was also performed with the program DNAML of the PHYLIP software package (Felsenstein, 1993). Accession numbers of the sequences included in the analysis are shown in Fig. A, available as supplementary material in IJSEM Online. The phylogenetic trees obtained strongly confirm that the new isolates should be classified within L. delbrueckii owing to their very low sequence divergence (identity of 99\%); the distance matrix tree (Fig. A) is available as supplementary material in IJSEM Online.

$16 \mathrm{~S}$ rRNA gene sequence similarity is not sufficient to guarantee species identity (Fox et al., 1992). Proteinencoding genes are more variable; in particular, the $\operatorname{rec} A$ gene has proved useful in the differentiation of closely related species with almost identical 16S rRNA gene sequences, including lactic acid bacteria species such as Lactobacillus plantarum, Lactobacillus paraplantarum and Lactobacillus pentosus (Torriani et al., 2001) or Lactobacillus casei, Lactobacillus rhamnosus and Lactobacillus zeae (Felis et al., 2001). Therefore, part of the recA gene was amplified using the degenerate primers recEXT-f (5'-GGCTATGAAACAAATTGAAAAACAATWYGGNAARGG-3') and recEXT1-r (5' -TGTTTAAACGGTGGAGCAACTTTRTTYTTNAC- $\left.3^{\prime}\right)$. The reaction mixture $(50 \mu \mathrm{l})$ contained $300 \mathrm{ng}$ template DNA, $100 \mu \mathrm{M}$ each dNTP, $1 \mu \mathrm{M}$ each primer, $2 \mathrm{mM}$ magnesium chloride, $5 \%(\mathrm{v} / \mathrm{v})$ DMSO and $4 \mathrm{U}$ Taq polymerase in a standard reaction buffer. After an initial denaturation of $5 \mathrm{~min}$ at $94^{\circ} \mathrm{C}, 30$ cycles of $1 \mathrm{~min}$ at $94^{\circ} \mathrm{C}$, $1 \mathrm{~min}$ at $50^{\circ} \mathrm{C}, 1 \mathrm{~min}$ at $72{ }^{\circ} \mathrm{C}$ and a final extension at $72{ }^{\circ} \mathrm{C}$ for 7 min were performed. Amplification products of the expected length of about $730 \mathrm{bp}$ were obtained for all strains tested.

A partial sequence of the $h s p 60$ gene was also amplified using the degenerate primers cpn-f (5'-CTTGGGCCCAAAAGGCMGNAAYGTNGT- $3^{\prime}$ ) and cpn-r (5'-CCAACCGTTCTTGCAATTTTTCNCKRTCRAA- $3^{\prime}$ ). The reaction mixture and amplification programme were the same as those reported above, except that an annealing temperature of $55^{\circ} \mathrm{C}$ instead of $50^{\circ} \mathrm{C}$ was used. Amplicons of the expected length of about $1000 \mathrm{bp}$ were obtained for all the strains. Sequencing reactions were performed at the Biomolecular Research Centre (BMR), University of Padua, Italy. The partial recA and $h s p 60$ sequences obtained for the strains were aligned as described for 16S rRNA gene sequences and showed very low divergence (identity of $99 \%)$.

RAPD analysis was carried out using three different primers: Coc1 (5'-AGCAGCGTGG-3') (Cocconcelli et al., 1995), M13 (5'-GAGGGTGGCGGTTCT-3') (Stendid et al., 1994) and D8635 (5'-GAGCGGCCAAAGGGAGCAGAC$3^{\prime}$ ) (Akopyanz et al., 1992), as described in the respective references except for the addition of $5 \%(\mathrm{v} / \mathrm{v})$ DMSO in each reaction mixture. Pattern analyses of the amplification products, separated in agarose gels and stained with ethidium bromide, were performed with the GELCOMPAR software (Applied Maths) with the DICE coefficient and UPGMA as calculation and clustering options. AFLP ${ }^{(i \times}$ analysis of the four cultures was performed at the $\mathrm{BCCM}^{(\mathrm{m}} / \mathrm{LMG}$ Bacteria Collection (Laboratorium voor Microbiologie, Universiteit Gent, Belgium). Comparison of AFLP (ii (Fig. 1 and Fig. B, available as supplementary material in IJSEM Online) and RAPD profiles (Fig. C, available as supplementary material in IJSEM Online) demonstrated the genomic coherence of the four strains, their non-clonality and their close relationship with other strains of the species L. delbrueckii.

DNA-DNA hybridization testing was performed among the type strains of each subspecies at the $\mathrm{BCCM}^{\circledR} / \mathrm{LMG}$ Bacteria Collection. Hybridization values above $70 \%$, usually considered the threshold for species delineation, were obtained with the type strains of the other three subspecies. DNA-DNA relatedness values were calculated on a minimum of four hybridizations and reciprocal reactions were also performed. Results are as follows, with the difference between reciprocal values shown in parentheses: strain $\mathrm{NCC}^{2} 5^{\mathrm{T}}$ shared $78 \%$ (5), $79 \%$ (3) and $86 \%$ (15) relatedness with $L$. delbrueckii subsp. delbrueckii LMG $6412^{\mathrm{T}}$, L. delbrueckii subsp. lactis LMG $7942^{\mathrm{T}}$ and L. delbrueckii subsp. bulgaricus LMG $6901^{\mathrm{T}}$ respectively. The level of hybridization between $L$. delbrueckii subsp. delbrueckii LMG $6412^{\mathrm{T}}$ and L. delbrueckii subsp. lactis LMG $7942^{\mathrm{T}}$ was $92 \%(6)$, and between L. delbrueckii subsp. delbrueckii LMG $6412^{\mathrm{T}}$ and L. delbrueckii subsp. bulgaricus LMG $6901^{\mathrm{T}}$ was $82 \%(18)$; genomic similarity between $L$. delbrueckii subsp. lactis LMG $7942^{\mathrm{T}}$ and $L$. 


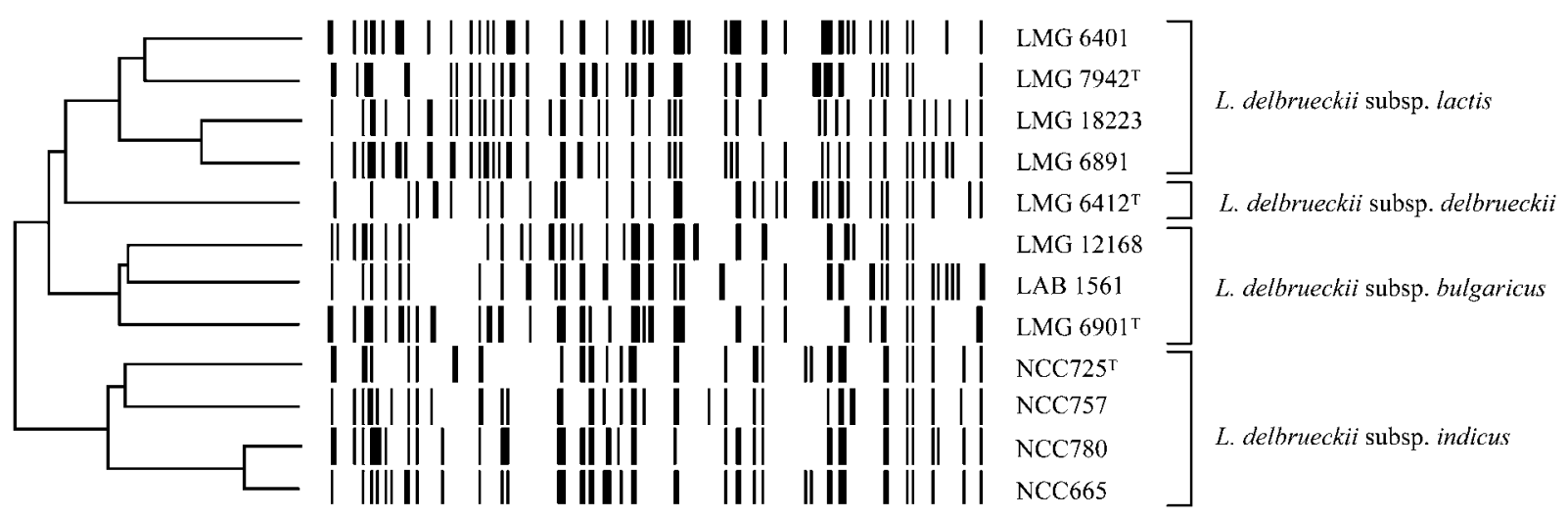

Fig. 1. Partial dendrogram of the cluster analysis of the AFLP ${ }^{\circledR}$ DNA fingerprints of the strains investigated and reference strains of the L. delbrueckii subspecies. A complete dendrogram including other strains and species of the Lactobacillus acidophilus complex is available as supplementary material in IJSEM Online (Fig. B).

delbrueckii subsp. bulgaricus LMG $6901^{\mathrm{T}}$ was $74 \%$ (11). With this technique, the mean standard deviation is estimated to be 14 units (Goris et al., 1998).

These data demonstrated that the four strains belong to the same taxon, even though, owing to the standard error of the technique, the relative order of the relationships could not be evaluated.

DNA-DNA hybridization values, and $16 \mathrm{~S}$ rRNA, recA and hsp60 gene sequence analysis, confirm that the four strains constitute a homogeneous cluster belonging to the species L. delbrueckii. However, data obtained here and in Germond et al. (2003) suggest that they cannot be assigned to any of the three recognized subspecies of L. delbrueckii: (i) ARDRA (Germond et al., 2003) and subspecies-specific PCR data support their differentiation from $L$. delbrueckii subsp. lactis and L. delbrueckii subsp. bulgaricus; (ii) phenotypic traits distinguish them from $L$. delbrueckii subsp. delbrueckii (lactose fermentation) and from L. delbrueckii subsp. lactis (maltose and trehalose metabolism) (see Table A, available as supplementary material in IJSEM Online); (iii) lactose degradation is constitutive in the four strains but is regulated in L. delbrueckii subsp. lactis (Lapierre et al., 2002); and (iv) Lactobacillus delbrueckii subsp. bulgaricus is also able constitutively to degrade lactose but the four strains are negative for the specific PCR amplification for $\beta$-galactosidase (Germond et al., 2003). This evidence suggests that the four strains possess a unique genetic equipment for lactose degradation, which differs from that of the other recognized subspecies. Characterization of this equipment is beyond the scope of the present study, but it does provide proof that the four strains represent a separate subspecies. Moreover, molecular analysis, such as AFLP $^{(1 \times}$ and RAPD-PCR, indicated that the four strains represent a genomic, coherent, non-clonal distinct group within the species $L$. delbrueckii. The data presented highlight several peculiarities to the four strains (probably a result of their geographical isolation) that fulfil the requirements for the description of a new subspecies (Rosselló-Mora \& Amann, 2001) within L. delbrueckii. This description may avoid future incorrect identification of 'atypical' isolates of $L$. delbrueckii species. The name Lactobacillus delbrueckii subsp. indicus subsp. nov. is proposed for these strains. Owing to the high overall similarity with the other strains of the species, an emended description of $L$. delbrueckii is not required, except that the species now comprises four subspecies.

\section{Description of Lactobacillus delbrueckii subsp. indicus subsp. nov.}

Lactobacillus delbrueckii subsp. indicus (in'di.cus. L. masc. adj. indicus from India, referring to the geographical origin of the strains).

Cells are Gram-positive, catalase-negative rods with rounded ends, generally $0 \cdot 5-0 \cdot 8$ by $2-9 \mu \mathrm{m}$, occurring singly, in pairs and in short chains. Non-motile. Homofermentative, produces D-lactic acid exclusively. Growth occurs at $45^{\circ} \mathrm{C}$ but not at $15^{\circ} \mathrm{C}$. Glucose, fructose, mannose and lactose are fermented by all strains, while fermentation of sucrose and $N$-acetylglucosamine is more variable. Glycerol, erythritol, arabinose, ribose, xylose, adonitol, methyl $\beta$-Dxyloside, galactose, rhamnose, dulcitol, inositol, mannitol, sorbitol, methyl $\alpha$-D-mannoside, methyl $\alpha$-D-glucoside, amygdalin, arbutin, aesculin, salicin, cellobiose, maltose, melibiose, trehalose, inulin, melezitose, raffinose, starch, glycogen, xylitol, gentiobiose, D-turanose, D-lyxose, Dtagatose, fucose, arabitol, gluconate, 2-ketogluconate and 5-ketogluconate are not fermented. Arginine is not deaminated. Growth is observed in MRS plus $2 \cdot 5 \%(\mathrm{w} / \mathrm{v}) \mathrm{NaCl}$, except for strain NCC780; none of the strains grows in MRS plus $5 \%(\mathrm{w} / \mathrm{v}) \mathrm{NaCl}$. All the strains grow in MRS at $\mathrm{pH} 3,4$ and 5 , but not at $\mathrm{pH} 7 \cdot 8$. Metachromatic granules are often observed after methylene blue staining.

The type strain, $\mathrm{NCC}^{2} 5^{\mathrm{T}}\left(=\mathrm{LMG} 22083^{\mathrm{T}}=\mathrm{DSM} 15996^{\mathrm{T}}\right)$, 
was isolated from a traditional Indian dairy fermented (type Dahi) product.

\section{Acknowledgements}

Ms Valérie Vaccarello De Icco is acknowledged for isolation of the bacterial strains from Indian dairy products.

\section{References}

Akopyanz, N., Bukanov, N. O., Westblom, T. U., Kresovich, S. \& Berg, D. E. (1992). DNA diversity among clinical isolates of Helicobacter pylori detected by PCR-based RAPD fingerprinting. Nucleic Acids Res 20, 5137-5142.

Cocconcelli, P. S., Porro, D., Galandini, S. \& Senini, L. (1995). Development of RAPD protocol for typing of strains of lactic acid bacteria and enterococci. Lett Appl Microbiol 21, 376-379.

Delley, M., Mollet, B. \& Hottinger, H. (1990). DNA probe for Lactobacillus delbrueckii. Appl Environ Microbiol 56, 1967-1970.

Felis, G. E., Dellaglio, F., Mizzi, L. \& Torriani, S. (2001). Comparative sequence analysis of a $r e c A$ gene fragment brings new evidence for a change in the taxonomy of the Lactobacillus casei group. Int J Syst Evol Microbiol 51, 2113-2117.

Felsenstein, J. (1993). PHYLIP (phylogeny inference package), version 3.5c. Department of Genetics, University of Washington, Seattle, USA.

Fox, G. E., Wisotzkey, J. D. \& Jurtshuk, P., Jr (1992). How close is close: $16 \mathrm{~S}$ rRNA sequence identity may not be sufficient to guarantee species identity. Int J Syst Bacteriol 42, 166-170.

Germond, J.-E., Lapierre, L., Delley, M., Mollet, B., Felis, G. E. \& Dellaglio, F. (2003). Evolution of the bacterial species Lactobacillus delbrueckii: a partial genomic study with reflections on prokaryotic species concept. Mol Biol Evol 20, 93-104.

Goris, J., Suzuki, K., De Vos, P., Nakase, T. \& Kersters, K. (1998). Evaluation of a microplate DNA-DNA hybridisation method compared with the initial renaturation method. Can J Microbiol 44, 1148-1153.

Kandler, O. \& Weiss, N. (1989). Regular, nonsporeforming grampositive rods. In Bergey's Manual of Systematic Bacteriology, vol. 2, pp. 1208-1234. Edited by P. H. A. Sneath, N. S. Mair, M. E. Sharpe and J. G. Holt. Baltimore: Williams \& Wilkins.

Kumar, S., Tamura, K., Jakobsen, I. B. \& Nei, M. (2001). MEGA2: molecular evolutionary genetics analysis software. Bioinformatics $\mathbf{1 7}$, 1244-1245.

Lapierre, L., Mollet, B. \& Germond, J.-E. (2002). Regulation and adaptive evolution of lactose operon expression in Lactobacillus delbrueckii. J Bacteriol 184, 928-935.

Marmur, J. (1961). A procedure for the isolation of DNA from microorganisms. J Mol Biol 3, 208-218.

Rosselló-Mora, R. \& Amann, R. (2001). The species concept for prokaryotes. FEMS Microbiol Rev 25, 39-67.

Stendid, G., Karlsson, J. O. \& Hogberg, N. (1994). Intraspecific genetic variation in Heterobasidion annosum revealed by amplification of minisatellite DNA. Mycol Res 98, 57-63.

Thompson, J. D., Gibson, T. J., Plewniak, F., Jeanmougin, F. \& Higgins, D. G. (1997). The CLUSTAL_X windows interface: flexible strategies for multiple sequence alignment aided by quality analysis tools. Nucleic Acids Res 25, 4876-4882.

Torriani, S., Zapparoli, G. \& Dellaglio, F. (1999). Use of PCR-based methods for rapid differentiation of Lactobacillus delbrueckii subsp. bulgaricus and L. delbrueckii subsp. lactis. Appl Environ Microbiol 65, $4351-4356$.

Torriani, S., Felis, G. E. \& Dellaglio, F. (2001). Differentiation of Lactobacillus plantarum, $L$. pentosus, and $L$. paraplantarum by recA gene sequence analysis and multiplex PCR assay with recA genederived primers. Appl Environ Microbiol 67, 3450-3454.

Weiss, N., Schillinger, U. \& Kandler, O. (1983). Lactobacillus lactis, Lactobacillus leichmannii and Lactobacillus bulgaricus, subjective synonyms of Lactobacillus delbrueckii subsp. lactis comb. nov. and Lactobacillus delbrueckii subsp. bulgaricus comb. nov. Syst Appl Microbiol 4, 552-557. 